\title{
Conflicts During The Planning Of INDiAn INDEPENDENCE AND ITS PARTITION IN POUR L'AMOUR DE L'INDE BY CATHERINE ClÉMENT AND INDIAN SUMmER BY ALEX VON TUNZELMANN. AN EMBODIMENT APPROACH TO VIOLENCE
}

\author{
TAGIREM GALLEGO GARCÍA \\ Universidad de Castilla-La Mancha \\ Tagirem.Gallego@uclm.es
}

Received: 15-09-2015

Accepted: 09-01-2016

\begin{abstract}
The end of the Raj and the British Empire had multiple consequences on Indian history, geography and society. While India was joyfully declared an independent nation, its partition caused innumerable violent episodes, the exodus of religious groups, Hindu-Muslim riots and conflicts with its new-born neighbour Pakistan. In such a tumultuous scenario, Gandhi's proclaimed message of ahimsa (non-violence) opposed the will of Muhammad Ali Jinnah, the founder of Pakistan, and the, until then, Viceroy Lord Louis Mountbatten who managed British Government policy. Pour l'amour de l'Inde (1993) by Catherine Clément, and Indian Summer. The Secret History of the End of an Empire (2007) by Alex von Tunzelmann both explore the last days of colonized India in detail and with a sharp eye on the events and personalities that shaped this new India. The literary reconstruction of historic events gives a new insight into the decisions which led to Indian independence and division. In both novels, the body plays an important role. With physical and metaphorical references, from the maternal body of India being tainted, to Gandhi's fasts and refusal of medication, the body is charged with political and symbolic meanings.
\end{abstract}

KEYwORDS: Indian independence, Partition, India-Pakistan, Historic novels, Mountbatten, Lady Edwina, Nehru, Body.

RESUMEN Conflictos durante la planificación de la independencia de la India y su partición en Pour l'amour de l'Inde de Catherine Clément e Indian Summer de Alex von Tunzelmann. Un acercamiento corpóreo a la violencia

El final del Raj y el Imperio británico tuvo múltiples consecuencias en la historia, geografía y sociedad india. Mientras que la India fue declarada nación independiente de forma pletórica, su partición provocó innumerables episodios violentos, éxodo de grupos religiosos, revueltas entre hindúes y musulmanes y conflictos con su recién nacido vecino Pakistán. En este clima inhóspito, el proclamado mensaje de ahimsa (no violencia) de Gandhi se oponía a la voluntad de Muhammad Ali Jinnah, fundador de Pakistán, y el hasta entonces virrey Lord Louis Mountbatten entablaba relaciones políticas con el gobierno británico. Pour l'amour de l'Inde (1993) de Catherine Clément, e Indian Summer. The Secret History of the End of an Empire 
(2007) de Alex von Tunzelmann exploran los últimos días de la India colonizada, con minucioso detalle sobre los sucesos y personalidades que dieron forma a la nueva India. La reconstrucción literaria de los hechos históricos ofrece una nueva mirada hacia las decisiones que llevaron a India a su independencia y su división. En ambas obras, el cuerpo tiene un valor primordial. Con referencias físicas y metafóricas, desde la India como un cuerpo maternal mancillado a los ayunos de Gandhi y su rechazo a la medicación, el cuerpo está cargado de significados políticos y simbólicos.

Palabras Clave: Independencia de la India, Partición, India-Pakistán, novela histórica, Mountbatten, Lady Edwina, Nehru, cuerpo.

Violence in any form (cultural, psychological, structural, etc.) is associated with degrading changes and destruction. When violence is presented at a physical level, it becomes more visible or evident than when it happens at a psychological level. In all societies, violence has been present. World history from the twentieth century has been witness to two world wars, innumerable armed conflicts, terrorism, genocides, religious riots and gender violence.

Violence and the body are strongly connected. Lauren B. Wilcox in her research on Bodies of Violence (2015) exposes the dehumanization of people during wars and armed conflicts, where human beings become injured or simply are transformed into dead bodies, deprived of any personal identity:

\begin{abstract}
States or groups make war and, in doing so, kill and injure people that other states are charged with protecting. The strategic deployment of force in the language of rational control and risk management that dominates security studies presents a disembodied view of subjects as reasoning actors. However, as objects of security studies, the people who are protected from violence or are killed are understood as only bodies: they are ahistorical, biopolitical aggregations whose individual members breathe, suffer, and die. In both cases, the politics and sociality of bodies are erased (Wilcox, 2015: 2).
\end{abstract}

The deployment of violence thus disembodies humanity or objectifies people in the interests of a country, a religion or any other cause. At a geopolitical level, while colonial empires were coming to an end, the rise of independent movements provoked both the creation of new nations and physical and cultural destruction ${ }^{1}$ in the form of human damage and death, the destruction of heritages, population exodus and religious hatred. Such is the case with India's struggle for independence: "From the ashes of a worldwide war, a new world was rising” (Von Tunzelmann, 2007: 136). Paradoxically,

\footnotetext{
${ }^{1}$ For a wider notion of "cultural violence", see Galtung 1990.
} 
its much awaited freedom from British power in 1947, would bring pain, hate and chaos, especially due to India's partition and the consequent rise of communalism and religious hatred.

The story of Partition has been told from different perspectives. Historiographically, the 'official' version of modern India, India's Struggle for Independence (1989), is the 'nationalist narrative', which opposes British rule and elaborates on the different civil rebellions, peasant movements and Gandhi's activism for self-rule, while dedicating only one chapter to the contradictory nature of "Freedom and Partition" (Chandra et al., 1989: 487-504). The reasons for the transition to independence are described as a combination of British weakness due to their involvement in the Second World War, the role of Jinnah as a possible collaborator of the Raj, and the Indian National Congress' failure to maintain Hindu-Muslim unity. Rather differently, Pakistani scholar Ayesha Jalal questions the surgical division between the Indian Congress' secularism and Jinnah and his Muslim League's communalism, and this author highlights the difficult task of transcending the limiting constraints of one's nation or religion, and being impartial while narrating such a painful historical event. She explains that "the psychological legacy of partition has left a much deeper impact on people's minds than the social, economic and political dynamics that led to the division" (Jalal, 1996: 681). Thus, the violent consequences and trauma of Independence and Partition at a personal level are more difficult to measure or narrate. This is where literature comes in. A literary approach to the historical events will, without eluding the facts, actors, numbers and dates, get to the core of the emotions and the psychological impact on society and the individual. For example, the work of Rituparna Roy, South Asian Partition Fiction in English from Khushwant Singh to Amitav Ghosh (2010) attempts to analyse narratives concerning Partition in Indian fiction from the mid-1950s to the late 1980s: Train to Pakistan (1956) by Khushwant Sigh, A Bend in the Ganges (1964) by Manohar Malgonkar, Ice-Candy Man (1989) by Bapsi Sidhwa, Clear Light of Day (1980) by Anita Desai, Midnight's Children (1980) by Salman Rushdie, and The Shadow Lines (1988) by Amitav Ghosh.

To offer another point of view, in this paper a literary analysis is presented on the historical events of Indian independence and its partition as narrated by two European women authors in their novels Pour l'amour de l'Inde (1993) by Catherine Clément and 
Indian Summer: The Secret History of the End of an Empire (2007) by Alex von Tunzelmann. The interaction both authors establish between literature and history offers an interdisciplinary approach and creates a better understanding of the convoluted process towards Indian independence. Considering the intrinsic relation between violence and body as presented by Wilcox, I will focus on three aspects to develop this paper. Firstly, I will contemplate India as a geographical and political body whose parts are being altered. The embodiment of India as a mother who is being desecrated will contain cruel episodes of anonymous victims of all religions and social backgrounds, as well as references to the violence of climate and nature. Secondly, I will consider the relation of violence and body in male figures, mainly in the three main characters in the plot of both novels: Lord Louis Mountbatten, Jawaharlal Nehru and Mahatma Gandhi. Mountbatten stands as a political figure, a highly-decorated naval hero, proud of his achievements. Nehru's periods of imprisonment are a test of the body, where the latter is confined to a small space and deprived of freedom. Regarding Gandhi, his voluntary fasts as a sign of protest and his experiments of brahmacharya (literally "going after Brahman", a spiritual practice of control of the senses and chastity) will make him a controversial figure. The third part is dedicated to female bodies, often the main protagonists in violent episodes - abducted, raped, abused, mutilated - and the least talked about. The role of Lady Edwina and female politicians in India will be crucial in understanding women as both victims and as agents for peace.

Pour l'amour de l'Inde by Catherine Clément and Indian Summer by Alex von Tunzelmann focus their narration on a tumultuous period of Indian history. Clément presents the facts of the planning of Indian independence in the form of a diary with an 'omnipresent look' from 1922 to 1948. Von Tunzelmann offers a wider scope of the events by narrating Indian history from 1577, where she compares the splendour of Mughal emperors to that of England which was an undeveloped nation at that time. Certainly, the physical conception of India is one that has witnessed change as an entity; its geography has expanded or divided according to its rulers and the manner in which they have drawn up borders. Indian independence in 1947 was followed by its partition with the creation of Pakistan. Sir Cyril Radcliffe, a London barrister, chosen by the British with the approval of Jinnah, was assigned the onerous and vulnerable job of drawing the lines of the partition (Clément, 1993: 197, Von Tunzelmann, 2007: 205). But ironically none of the leaders, Nehru in India and Jinnah in Pakistan, knew the real 
territories of their nations since "the boundaries between the two new states were not officially known until two days after they had formally become independent. And, astonishingly, few had foreseen that this division of territories and power would be accompanied by anything like the bloodbath that actually eventuated" (Pandey, 2011: 2). What was meant to be a peaceful process of farewell to British rule became a series of violent episodes in an apocalyptic atmosphere. In both novels emerges the image of a tainted and sacrificed India, a dishonoured mother whose body is being split and altered. Such imagery is strengthened with a series of metaphors or embodiments, which make India a feminine, living, suffering entity.

During their stay in India as Viceroy and Vicereine Louis, and Edwina Mountbatten would travel through different states. At one moment, their itinerary is described as "the royal tour ground on, zigzagging up through the belly of India and stopping in Bangalore, Mysore, Hyderabad, and Indore" (Von Tunzelmann, 2007: 66). This "belly" would engender two sons or "quarrelling siblings" (Chakrabarti, 2012), India and Pakistan, due to the painful process of "the partition of the subcontinent, the split which had ripped two wings off the body of India" (Von Tunzelmann, 2007: 2).

If India appears as a suffering mother on, what was supposed to be, its glorious day of freedom, England stands as a proud father who sees its educated child "open her wings":

the end of Empire was presented as the purpose of Empire - India was as a well-nurtured and fattened chick, raised to fly from the imperial nest while Britain, the indulgent parent, looked on with pride. And so the British were able to celebrate their loss alongside the Indians who celebrated their victory (Von Tunzelmann, 2007: 6).

Not only do these two countries play a familial role, but in the new geopolitical scenario, the United States comes on board as a helpful uncle to aid England to recover from post-war damages: "Britain was beginning to find out what it was like to be the humbled dependency of a much more powerful state [...] It looks like a pat on the back to us from a rich uncle who sees us turning over a new leaf' (Von Tunzelmann, 2007: $150)$.

It is clear that powerful nations are associated with paternal or male figures. Jinnah is also compared to the father of a new nation, and from Britain, Churchill supports him: 
"If Jinnah is regarded as the father of Pakistan, Churchill must qualify as its uncle; and, therefore, as a pivotal figure in the resurgence of political Islam.” (Von Tunzelmann, 2007: 148). On the contrary, maternal or feminine metaphors are associated with the weak, in this case, India. Catherine Clément in Pour l'Amour de l'Inde entitles Chapter Six as "Inde, ma mère au toit de neige", 2 evoking fragility or using a metaphor for "up is good", as up on the North was snowy Shimla, the favourite British settlement in India. Even 'Vande mataram' (Hail motherland), inherited from myths in the Ramayanas, the Mahabharata and the Puranas, is part of the Indian cultural imagination, which considers nation as motherland (Tripathy, 2014: 81). Such a tradition of nationalist iconography represents woman or mother as a metaphor of the bountiful and yet suffering land. It appears in Katherine Mayo's Mother India (1927), and is alluded to in Pour l'amour de l'Inde where Edwina is reading it:

— Un livre sur les Indes, j'imagine? dit Lord Louis affectueusement. Voyons... C'est bien cela. Mother India. Un classique.

- Très mauvais livre, fit Nehru vivement. Cette dame Mayo mériterait un procès en diffamation. Nous y sommes décrits comme des singes souillés en permanence, des sauvages sans âme et sans cœur... Ouvrage raciste! ${ }^{3}$

(Clément, 1993: 117).

Jawaharlal Nehru's frustration is common in both novels as he sees the plans for independence not matching the wishes of Congress for a united India. He also differs from the Mahatma in approaching problems and rejects Gandhi's mingling spirituality with politics. Nehru would describe Gandhi as "going round with ointment trying to heal one sore spot after another on the body of India, instead of diagnosing the cause of this eruption of sores and participating in the treatment of the body as a whole" (Von Tunzelmann, 2007: 174). At the turning point of the transfer of power from Britain to India, it is inconceivable to "treat" the whole body of India and the magnitude of the conflicts. We can also approach the body or the land partially through metaphors: Jaipur is described as "a pink metropolis set in the heart of princely Rajputana" (Von

\footnotetext{
${ }^{2}$ India, my mother with a snow roof. All quotations in French are translated to English by the author of this paper.

${ }^{3}$ — A book about India, I suppose? said Lord Louis affectionately. Let's see... Yes that's right. Mother India. A classic.

- A very bad book, said Nehru vividly. This lady Mayo deserves a trial for defamation. We are constantly described as dirty monkeys, soulless and heartless savages... Racist work!
} 
Tunzelmann, 2007: 301), the situation of Kashmir, between Pakistan and India, is described as "the eye of the storm" (Chakrabarti, 2012: 15) and Lord Louis Mountbatten is also worried, foreseeing the turmoil if Partition is agreed upon by both sides. Being responsible for the transfer of power from Britain to India, he is afraid "to put the responsibility for any of these mad decisions fairly and squarely on the Indian shoulders in the eyes of the world, for one day they will bitterly regret the decision they are about to make" (Von Tunzelmann, 2007: 185).

Effectively, the decisions for Indian independence and its partition took place and the future was uncertain and not peaceful as expected, but rather violent. Partition between India and Pakistan caused uncountable episodes and adversities from both sides of the new borders: "Nous avons des émeutes au Bihar, à Calcutta, Bombay aussi s'est enflammée. Calcutta surtout!"” (Clément, 1993: 53). Riots were mainly religious and communal in nature: Hindus were slaughtered by Muslims, Muslims by Hindus in an unstoppable vicious circle. They attacked each other killing pigs in front of mosques and cows in front of temples. India's body, which hosted all religious manifestations, was desecrated: “Aux haines religieuses entre hindous et musulmans s'ajoutait le péril sikh; depuis qu'ils avaient compris que leur Penjab serait partagé par le milieu, les sikhs avaient retrouvé leurs traditions guerrières" (Clément, 1993: 203). The Punjab became a refugee camp, where thousands (or more) Hindus moved to India, thousands (or more) of Muslims moved to Pakistan, and "à travers le Penjab [...] l'immense masse des hommes et des femmes fuyaient d'un pays à l'autre, sans vraiment savoir pourquoi"6 (Clément, 1993: 291).

A strong recurring image amongst Partition's violent episodes is that of trains whose passengers have been massacred: "An image of overloaded trains, with people pasted on to every possible part of its body... has been permanently imprinted on the nation's collective imagination" (Roy, 2010: 35). Alex von Tunzelmann and Catherine Clément both refer to these cruel episodes, but to dignify the anonymity of the victims, to make them more than just a piece of flesh, more than just a dead body, Catherine Clément

\footnotetext{
${ }^{4}$ We have riots in Bihar, Calcutta, Bombay is also on fire. Especially Calcutta!

5 To religious hatred between Hindus and Muslim was added the Sikh risk; since they understood that their Punjab would be divided in two, Sikhs found again their warrior traditions.

${ }^{6}$ Through the Punjab ... the immense mass of men and women fled from one country to another, without really knowing why.
} 
gives them a name. By narrating short episodes with proper names instead of a mass number of victims, she offers a closer look at the impact of the inhuman events. She introduces to the reader the story of Khushwant, a Sikh humiliated by Muslims (Clément, 1993: 282-285) and the experience of Keshav, a Jain survivor of a slaughter while he travelled in a train full of Muslims (Clément, 285-287). The writer had personally met Keshav while she was in India doing her research for the novel. By interviewing him and making his story known, she recovers the memory of Partition through a personal story and thus brings forth the human element within these anonymous victims.

Unfortunately, uncountable stories remain untold about the massacres that female bodies suffered in a besmirched motherland: "La femme à l'œil sorti de son orbite, et qui tenait un nourrisson ensanglanté, le ventre ouvert. La vieille hébétée aux mains coupées, et les fumées noires des bûchers pour les morts... " " (Clément, 1993: 170).

Apart from the cruelty of human actions towards other fellow countrymen and women, we could wonder about the violence of nature. India's climate is extreme, the heat can be unbearable for foreigners and when the expected rains come, monsoons can devastate the land with floods. Natural disasters also provoke human death and material damages. Von Tunzelmann makes reference to an earthquake that hit Bihar on 15 January 1934 and caused (an estimated) 20,000 deaths: "Gandhi visited Bihar in March, and spoke to the bereaved, destitute and homeless people. The earthquake, he told them, "is a chastisement for your sins". And the particular sin that he had in mind was the enforcement of Untouchability" (Von Tunzelmann, 2007: 95). Untouchability, which had been banned by the British continue(d) to exist. This is also a form of violence towards the body and thus against human dignity, yet Gandhi'explanation for natural disaster would be that of divine punishment. Opposed to this idea, Sarojini Naidu, who rarely appears in Indian Summer, but becomes an active character in Pour l'amour de l'Inde, speaks about the nature of violence and the violence of nature: "Tout est d'une incroyable pureté, les cimes, les arbres, les ombres mauves à l'horizon, le silence... On

\footnotetext{
${ }^{7}$ The woman with the eye out of its socket, and holding a bloody infant, belly open. The old dazed with severed hands and black smoke pyres for the dead.
} 
dirait que rien ne s'est passé en Inde; la nature ne se soucie ni des massacres ni de la mort de notre Mahatma; elle oublie ${ }^{8 "}$ (Clément, 1993: 27).

After considering India as a suffering female body, it is also important to observe the male roles in both the novels. Within the multitude of anonymous victims there are men standing out of the crowd with names, identities and decisive ideas and actions that would change the course of history. It actually seems that the Independence and Partition of India were "in their hands", that is: Lord Louis Mountbatten, Jawaharlal Nehru, Mohandas Karamchand Gandhi and Muhammad Ali Jinnah. All of them were confronted by violence, by personal suffering and general pain due to the diverse cruel episodes and civil war ambience in the new India and Pakistan. Jinnah in both novels is often described as the self-proclaimed first man of his new nation Pakistan, not emotional, or reluctant to show his feelings, nor willing to dialogue. Journalist Mildred Talbot described Jinnah as a man who "looked like a walking, talking corpse" (Von Tunzelmann, 2007: 238). His physical aspect suggests death and frigidity. From the British side, there is Lord Louis, "Viscount Mountbatten of Burma, the new ViceroyDesignate, forty-six years old, handsome and gleaming in his full dress uniform, with rows of medals stretching from breastbone to armpit" (Von Tunzelmann, 2007: 161). He also appears as a cold figure, proud of his insignias and his genealogy. However, he has a pivotal role in British-Indian relations by being the last Viceroy of colonial India and by trespassing political etiquette to become close friends with Nehru and Gandhi and be appreciated by the Indian population. This respect is also achieved by his wife Lady Edwina, due to her commitment for civil and humanitarian causes during the war in Europe and during the massacres in a divided India. Jawaharlal Nehru would soon admire this couple and develop bonds of friendship with both, and more intimately with Edwina, a fact that Lord Louis accepted and respected. Nehru had experienced prison several times, a lack of freedom for the body that meant for him a time for learning and freeing the mind. A reduced space would be enough for him to practice yoga: "Dans la cellule numéro huit, la tête en bas et les pieds en l'air, Jawaharlal Nehru faisait son yoga matinal $^{9 "}$ (Clément, 1993: 30). Prison was the place where he read Verlaine and felt

\footnotetext{
8 Everything is incredibly pure, the summits, the trees, the mauve shadows on the horizon, the silence... It seems that nothing has happened in India; Nature does not care about massacres nor about the death of our Mahatma; she forgets.

${ }^{9}$ In cell number eight, head down and feet in the air, Jawaharlal Nehru practiced his morning yoga.
} 
motivated to learn French. A reduced space which confines the body, inflicting the violence of lack of freedom, meant for Nehru a space for meditation and creation. Imprisoned at Dehra Dun at the foot of the Himalayas he spun what would be the wedding dress of Indira: "He spent his time planting an English country garden of sweet peas and nasturtiums, and over the course of nine months spun 112,500 yards of yarn some of which Indira would wear as her wedding sari, in place of the usual silk" (Von Tunzelmann, 2007: 110). Apart from Nehru's role as hero, father and the first Prime Minister of Independent India, he also represents in both novels sensuality. His relationship with Edwina is narrated in a more platonic way in Indian Summer, whereas in Pour l'amour de l'Inde, several erotic references give a clue of the nature of their rapport, described also as physical and passionate. After Edwina visited a small village near Delhi by herself, she explained to Nehru what she had seen, and he works as the agent who would introduce her to the mysteries of India:

— Et dans l'intérieur du temple se trouve le lingam.

— Le lingam... murmura Edwina, songeuse. Je ne l'ai pas vu.

- Mais vous en connaissez l'existence, je vois.

Edwina le regarda en face.

— Je connais la nature de ce fétiche, en effet, dit-elle en rosissant légèrement.

- Ce que vous appelez fétiche est le symbole même de la vie, madame, répliqua Nehru. On l'arrose de lait et de miel, et d'ailleurs il n'existe pas sans son complément, le...

- Je sais, coupa Edwina. Donc, dans le temple, si j'y retourne...

- Vous n'y retournerez pas seule! J'irai avec vous. Je vous montrerai le lingam ${ }^{10}$ (Clément, 1993: 118).

That conversation contains sexual connotations which suggest the attraction and desires to each other. During the violent climate of the new India, they promised to prioritize work over their personal relationship, but in the coming years, after the Mountbattens left for England, Edwina and Nehru continued in touch by exchanging letters and they managed to meet both in England and in India. During those meetings they could enjoy

\footnotetext{
${ }^{10}$ And in the temple there's the lingam. /The lingam ... Edwina murmured thoughtfully. I did not see it./ But you know about its existence, I see. / Edwina looked at him in the face. - I know the nature of this fetish, in fact, she said, blushing slightly. / What you call fetish is the symbol of life, madame, replied Nehru. It is sprinkled with milk and honey, and besides it does not exist without its complement, the .../ I know, Edwina stopped. So in the temple, if I go again .../ You will not go alone! I'll go with you. I will show you the lingam.
} 
the freedom of their bodies: "the two of them, alone at last in the privacy of her estate, were able to talk, laugh and cry together, to embrace, and to press each other's hands on walks by the river." (Von Tunzelmann, 2007: 337) and "il lui ferma la bouche d'un baiser $^{11 "}$ (Clément, 1993: 441).

Gandhi's relation to the body is also interesting. Here we will consider his experiments with fasting and his ideas of brahmacharya. Firstly, the image most of the world has of Gandhi is that of a smiling old man dressed in a white piece of cloth, which is the 'khadi', “ce khâdi dont le Mahatma avait fait l'emblème de la résistance à l'occupant anglais ${ }^{12 "}$ (Clément, 1993: 36). His body becomes the bearer of a symbol, that handmade fabric, against British rule. This would provoke anger in Churchill, and both Catherine Clément (1993: 87) and Alex von Tunzelmann recall his harsh words to Indians in general and particularly to Gandhi: "In London, Churchill launched into an outraged condemnation of the spectacle of 'a seditious Middle Temple lawyer, now posing as a fakir of a type well-known in the East, striding half-naked up the steps of the Vice-regal palace" (Von Tunzelmann, 2007: 87). Although Gandhi had studied in England and adopted European manners for a while, he eventually opposed the British and modernity, proclaiming Hind swaraj or self-rule. He refused to have his dying wife Kasturba injected with penicillin: "Je suis tout à fait hostile aux traitements par injection; ils ne sont pas naturels. Et ce qui n'est pas naturel n'est pas bon pour l'humanité ${ }^{13}$ " (Clément, 1993: 33). As a sign of protest he would fast for days, only nurturing his body with sips of water. Such exercise would be a mental challenge but a form of violence to the self, by depriving the body of "well-being needs" (Galtung, 1990: 292). His rigid opinions and opposition to foreign rule, his movements of passive resistance, civil disobedience and non-violence had all been influenced by Kasturba's character. These words are attributed to him: "I learned the lesson of non-violence from my wife" (Von Tunzelmann, 2007: 23). From one perspective, apparently, he seems a strong defender of feminism, but from the other, he is still a controversial figure, especially regarding his 'brahmacharya experiments' during 1946 and 1947: "the aged Mahatma had been 'testing' his vow of celibacy by sleeping at night in bed with a

\footnotetext{
${ }^{11}$ He shut her mouth with a kiss.

${ }^{12}$ This khadi became, due to the Mahatma, the emblem of the resistance against the English.

${ }^{13}$ I am quite hostile to injection treatments; they are not natural. And what is not natural is not good for mankind.
} 
naked or partially clothed woman. The object of the experiments was to transcend physical arousal" (Von Tunzelmann, 2007: 144). By experimenting against the nature of his body, he was using women's bodies with the aim of attaining sainthood and spreading or imposing the message of chastity in his ashram.

However contentious the figure of Gandhi might be, it is attributed to Gandhism that women were distinguished in Indian politics: "Non-violence, passive resistance and boycotts were all tactics which could be practiced by women without breaking social conventions" (Von Tunzelmann, 207: 170). By 1937, Nehru had insisted that the Congress manifesto pledge to remove all social, economic and political discrimination against women. However, behind this image of feminist progress lay a shadow of female distress.
At Calcutta in 1946, and subsequently, the vengeance of the rioters had been wreaked deliberately on women. As the great migration and great slaughters following partition got underway, so too did a sustained and brutal campaign of sexual persecution. The use of rape as a weapon of war was conscious and emphatic. On every side, proud tales were told of the degradation of enemy women. Thousands of women were abducted, forcibly married to their assailants, and bundled away to the other side of the border. Many never saw their families again. Thousands more were simply used and then thrown back into their villages. There were accounts of women who had been held down while their breasts and arms were cut, tattooed or branded with their rapists' names and the dates of their attacks (Von Tunzelmann, 2007: 260).

Pour l'amour de l'Inde and Indian Summer gives an account of the love triangle of the Mountbattens and Nehru during the troubled period of Indian process towards independence. Yet both novels explode with monstrous images of victims (Clément, 1993: 254, 257; Von Tunzelmann, 2007: 251), the anonymous protagonists of the human and moral tragedies that took place in India and Pakistan: "Sexual violence reduces the victims to the status of objects" (Khanna, 2014: 19). Khanna defends the narration of traumatic memory as an effective means to dignity, to return to personhood. The suffering of women is rooted in Indian national culture and gendered nationalism, thus linked to the myths that motherhood is best realized when dedicated to the cause of the nation; while wifehood is obtained if used as the source of strength for the heroic husband (Tripathy, 2014: 80). Wifehood is also bravely shown when women aresacrified in honour of the dead husband as satis, "celles qui ont décidé de se jeter vivantes dans le bûcher funèbre de leurs époux, et qui, douze jours plus tard, ont été 
consacrées déesses $^{14 "}$ (Clément, 1993: 351). This practice of "burning of live Hindu widows on the funeral pyres of their dead husbands was banned in 1829" (Von Tunzelmann, 2007: 16). This self-inflicted act of violence by committing suicide would paradoxically elevate women to the divine.

Amongst the anonymous female bodies in both novels stands Lady Edwina who also experiences violence at both personal and external levels and becomes an agent for peace and solace by involving herself in humanitarian actions and staying "face to face" with refugee women and thus establishing an informality that was a departure from the style of previous vicereines" (Von Tunzelmann, 2007: 183). She would not find happiness in her married life, but despite her adventures with lovers, Lord Louis Mountbatten would be her life companion: "Edwina trompait son mari, elle trompait son amant, elle trompait le monde entier, c'était la guerre, y aurait-il un jour une vie sans mensonges? ${ }^{15 "}$ (Clément, 1993: 29). She suffered from tedium, but her encounter with death and cruelty during the slaughter episodes of Partition made her commit to humanitarian causes to fight against violence by providing the victims with medicine, food and clothes. She was involved in macabre situations and coped with them by offering her helping hand: "She stopped her car when she saw injured or dead people, got out, dodged bullets, and retrieved their bodies to take them to hospitals or morgues" (Von Tunzelmann, 2007: 269). In both novels, she is described as a brave woman, compared to Racine's Berenice in Pour l'amour de l'Inde. In her last days, she only seemed to be intimately at ease with Nehru's epistolary exchange: "Edwina sat down and poured her heart out in a letter to Jawahar" (Von Tunzelmann, 2007: 314).

As we have observed in this paper, by focusing on India as a body and on the male and female bodies represented in both novels, the embodiment approach to violence makes it clear that the aggressions and cruelty towards the human being minimize the individual characters to objectification; violence degrades and dehumanizes, it demeans the person to a number or a piece of flesh. As quoted by the author of Indian Summer, "in Stalin's famous words, one death is a tragedy; one million deaths is a statistic" (Von Tunzelmann, 2007: 266). Whereas the death of Gandhi, Edwina, Nehru and Lord Louis

\footnotetext{
${ }^{14}$ Those (widows) who have decided to throw themselves alive in the burning pyres of their husbands, and who, after twelve days, are consecrated goddesses.

${ }^{15}$ Edwina cheated on her husband, she cheated on her lover, she deceived the whole world, it was the war, would there be one day a life without lies?
} 
were ritually celebrated as a homage to their honour and memory, statistically there is no objective data of the number and identities of the anonymous victims during IndiaPakistan conflicts: "It has proven much more difficult to arrive at a consensus figure on the numbers of persons who died as a consequence of the violence that occurred during the impending partition, the partition itself, and after it in the misery of the refugee camps" (Brass, 2003: 75).

\begin{abstract}
'One million dead': This is the most convenient number to have come out of the wildly varying estimates of how many people may have been killed following partition. Mountbatten preferred the lowest available estimate, which was 200,000 , and has been widely condemned for it: the denial of holocaust is always a sticky business, and yet more so when one may be implicated personally. Indian estimates have ranged as high as 2 million. Many historians have settled for a figure of somewhere between half a million and 1 million (Von Tunzelmann, 2007: 265).
\end{abstract}

Statistics do not depict the psychological impact and pain that such conflicts produce in a personal and collective imagination. The role of historical novels such as Pour l'amour de l'Inde and Indian Summer help complete an emptiness that history has not reached. The literary or novelized reconstruction of events keeps memories alive, and the narration of disasters offers dignity to the victims, sometimes a name.

Regarding the male and female body representations, India is still attached to its cultural roots. Its land appears as a suffering mother upset by its wretched children, India and Pakistan. It is also the land for prototypical male figures: a hero, Nehru as Prime Minister, Gandhi as a spiritual leader, whereas it seems to offer also space for women's rights. Nevertheless, both novels offer horrible images of tortured and objectified women and its narration might help de-membered women to be re-membered.

\title{
WORKS CITED
}

BRASS, PAUL R (2003). "The Partition of India and retributive genocide in the Punjab, 1946-47: means, methods, and purposes", Journal of Genocide Research, Vol. 5, $\mathrm{N}^{\mathrm{o}}$ 1, 71-101. DOI: <http://dx.doi.org/10.1080/14623520305657> accessed 12 January 2016.

Chakrabarti, Shantanu (2012). "Quarreling Siblings or Friendly Neighbours? Turbulent Nature of Indo-Pakistan Relationship since 1947”, UNISCI Discussion Papers, $\mathrm{N}^{\mathrm{o}} 29,9-33$.

DOI: $\quad<$ http://dx.doi.org/10.5209/rev_UNIS.2012.n29.40656> accessed 12 January 2016. 
Chandra, Bipan, Mukherjee, Mridula, Mukherjee, Aditya, Mahajan, Sucheta, PANIKKAR, K.N. (1989). India's Struggle for Independence, New Delhi: Penguin Books.

Clément, CAtherine (1993). Pour l'amour de l'Inde, Paris: Flammarion.

Galtung, Johan (1990). "Cultural Violence”, Journal of Peace Research, Vol. 27, No. 3, 291-305. DOI: <http://dx.doi.org/10.1177/0022343390027003005> accessed 12 January 2016.

Jalal, Ayesha (1996). 'Secularists, Subalterns and the Stigma of 'Communalism': Partition Historiography Revisited”, Modern Asian Studies, Vol. 30, № 3, 681737. DOI: <http://dx.doi.org/10.1017/S0026749X00016644> accessed 12 January 2016.

KHANNA, TANVI (2014). "Silence, Survival and Recuperation: Reading Women's Experiences in Partition Literature", Research Journal of English Language and Literature (RJELAL), Vol. 2, Issue. 3, 19-25.

Pandey, Gyanendra (2011). Remembering Partition. Violence, Nationalism and History of India, Cambridge: Cambridge University Press.

Roy, Rituparna (2010). South Asian Partition Fiction in English from Khushwant Singh to Amitav Ghosh, Amsterdam: Amsterdam University Press.

Tripathy, ANJAly (2014). "History is a Woman's Body: A Study of Some Partition Narratives", Odisha Review, 80-84.

Von Tunzelmann, Alex (2007). Indian Summer. The Secret History of the End of an Empire, London: Pocket Books.

WilcoX, LAUREN B. (2015). Bodies of Violence. Theorizing Embodied Subjects in International Relations, Oxford: Oxford University Press. DOI: $<$ http://dx.doi.org/10.1093/acprof:oso/9780199384488.001.0001> accessed 12 January 2016.

TAGiRem GALlego GARCÍA is PhD candidate at the University of Castilla-La Mancha (Spain). Her research is on the image of India in Western literature, women travellers in colonial and independent India. Her work is being supported with a predoctoral contract of UCLM, financed by the European Social Fund (ESF) [2014/10340].

ORCID iD http://orcid.org/0000-0003-2309-4065 